\begin{tabular}{ll}
\hline & $\begin{array}{l}\text { Kastamonu Eğitim Dergisi } \\
\text { Kastamonu Education Journal }\end{array}$ \\
$\begin{array}{l}\text { Eylül 2019 Cilt:27 Sayı:6 } \\
\text { kefdergi.kastamonu.edu.tr }\end{array}$ & Başuru Tarihi/Received: 05.10 .2018 \\
Kabul Tarihi/Accepted: 17.02 .2019 \\
Dol: $10.24106 /$ kefdergi.3379
\end{tabular}

\title{
Fen ve Teknoloji Dersinde Dijital Öyküleme Sürecinde Yaratıcı Drama Kullanımının Öğrencilerin Bilimsel Yaratıcılıkları ve Dijital Öyküleri Üzerindeki Etkisi
}

\section{The Effect of Using Creative Drama in the Digital Storytelling Process on Students' Scientific Creativity and Digital Story in Science and Technology Class}

Öz

\author{
Gözen AKGÜL ${ }^{1}$, IşıI TANRISEVEN²
}

Bu araştırmada, 7. Sınıf fen ve teknoloji dersinde dijital öyküleme sürecinde yaratıcı drama kullanımının öğrencilerin bilimsel yaratıcılığı ve dijital öyküleri üzerindeki etkisini incelemek amaçlanmıştır. Araştırma, karma yöntem desenlerinden açımlayıcı sıralı karma yöntem desenine uygun olarak düzenlenmiştir. Araştırmanın nicel boyutunda dijital öyküleme sürecinde yaratıcı drama kullanımının, öğrencilerin; bilimsel yaratıcılıkları üzerindeki etkilerini incelemek için "Öntest-Sontest Kontrol Gruplu Yarı Deneysel Araştırma Modeli” uygulanmıştır. Araştrrmanın nitel verileri ise açık uçlu soru formu ve dijital öyküleme rubriği ile toplanmıştır. Araştırma sonucu dijital öyküleme sürecinde drama kullanımının 7. sınıf öğrencilerinin bilimsel yaratıcılıkları üzerinde olumlu yönde etkiye sahip olduğunu ortaya koymuştur.

Anahtar Kelimeler: dijital öyküleme, yaratıcı drama, bilimsel yaratıcılık

\begin{abstract}
In this study, it is aimed to investigate the effects of creative drama use in the digital storytelling process on students' scientific creativity and digital stories in the 7th Grade Science and Technology course. The research has been designed in accordance with an explanatory sequential mixed method design from among mixed method designs. In the quantitative dimension of the study, Semi-Experimental Research Model with pre-test post-test control group was applied to examine the effects of creative drama use on students' scientific creativity in the digital storytelling process. Qualitative data of the research were collected through open-ended questionnaire and digital storytelling rubric. The research has revealed that the use of drama in the digital storytelling process had a positive effect on the scientific creativity of $7^{\text {th }}$ grade students in the science and technology class.
\end{abstract}

Keywords: digital storytelling, creative drama, scientific creativity

1. Tömük Hacı Recep Yaşa Ortaokulu, Mersin, Türkiye; http://orcid.org/0000-0002-5558-706X

2. Mersin Üniversitesi Eğitim Fakültesi, Mersin, Türkiye; http://orcid.org/0000-0001-5884-2807

Atıf / Citation: Akgül, G. \& Tenrıseven, I. (2019). Fen ve teknoloji dersinde dijital öyküleme sürecinde yaratıcı drama kullanımının öğrencilerin bilimsel yaratıcılıkları ve dijital öyküleri üzerindeki etkisi. Kastamonu Education Journal, 27(6), 2501-2512. doi:10.24106/kefdergi.3379 


\section{Extended Abstract}

In this research, the aim was to reveal the effect of using creative drama in the digital storytelling process on 7th Grade students' scientific creativity and digital stories in the Science and Technology course. The research was implemented with 50 students attending classes at a Intermediate School in the $7^{\text {th }}$ grade. Twenty-five out of 50 students were designated as experiment and 25 of them as control group. The research has been organized in accordance with an explanatory sequential mixed method design from among mixed method designs. In compliance with this design, quantitative data were collected first and then qualitative data were collected to support quantitative data. In the quantitative dimension of the study, Semi-Experimental Research Model with Pre-test-Posttest Control Group was applied to examine the effects of creative drama use on students' scientific creativity in the digital storytelling process.

In the research, Scientific Creativiyt Test was used to measured studens' scientific creativity levels. "Scientific Creativity Test" was developed by Hu and Adey (2002) and adapted to Turkish by Deniş Çeliker and Balım (2012). Quantitative measurement before and after the experiment were applied to both groups as pretest and posttest. Qualitative data of the research were collected through open-ended questionnaire and digital storytelling rubric. The open-ended questionnaire was created by the researcher in order to specify students' opinions about the use of creative drama in the digital storytelling process and was applied to experimental group students after the research. Furthermore, "Digital Storytelling Rubric" has been used to determine the quality of the digital stories that students have created during the digital storytelling process. This rubric has been composed of categories of story's objective, its point of view, significant question, content selection, sound clarity, verbal expression pace, meaningful sound (music) item, quality of pictures, story length as well as use of grammar and language.

The research was carried out by the researcher himself in the experimental and control groups. In the research, after the gains of the 7th grade Light Unit, 5 groups of 5 students were formed from the students in the experimental and control groups. Each group was asked to create a digital story throughout the research. In the experimental group, the lessons were taught using the creative drama method along with the digital storytelling process. In the control group, the lessons were taught using only digital storytelling process. At the end of the study, the scientific creativity scale was applied to the experimental and control groups as the post test. In addition, an open-ended questionnaire was applied to determine the opinions of the students in the experimental group about the digital storytelling process. The quality of the digital stories of both groups was determined by Digital Storytelling Rubric.

Independent sample T-test has been applied to determine whether students' scientific creativity in science and technology classes differed between the experimental and control groups. The data obtained from open-ended questions were analyzed through content analysis in order to determine the opinions of the students in the experimental group about the digital storytelling process. Each of the digital stories is coded as D1, D2, D3, D4 and D5. The arithmetic mean of the expert evaluations for each digital story evaluation was obtained.

The research has revealed that the use of drama in the digital storytelling process had a positive effect on the scientific creativity of $7^{\text {th }}$ grade students in the science and technology class, The findings obtained from the qualitative data of the research have been proven to be supporting the quantitative data. It has been determined that the effects of creative drama use on scientific creativity processes in digital storytelling process are gathered under three themes as fluency, flexibility and originality. Moreover, it has been determined that the qualities of the stories of experimental group using drama in the digital storytelling process were higher than the non-drama using control group in the digital storytelling process. 


\section{Giriş}

Teknolojik gelişmelerin yaşamın her alanında belirgin bir şekilde görüldüğü günümüzde fen eğitiminin önemi yadsınamaz. Fen, yaşamın her aşamasında yaratııılık bileşenlerini etkileyen bir süreçtir. Çünkü fen eğitimi kişinin çevresindeki problemleri tanımasını, gözlem yapmasını, hipotez kurmasını, deney yapmasını, sonuç çıkarmasını, analiz etmesini, genelleme yapmasını ve elde ettiği bilgi ve gerekli becerileri uygulamasını gerektirmektedir (Saxena, 1994). Fen bilgisi derslerinin kazanım ve içeriği öğrencilere edindirilirken çağdaş yöntem ve tekniklerin kullanılarak öğrencilerin yaratıcılıklarının ortaya çıkarmasında önem taşımaktadır (MEB,2000). Bu anlamda günümüz fen programlarında da bireylerin fen okuryazarı olması için sahip olmaları gereken beceriler arasında yaratıcılık önemli bir yer tutmaktadır. Son yıllarda uygulanan öğretim programlarında fen okuryazarlığı içinde yaratıcılık, girişimcilik ve analitik düşünme becerileri programa eklenmiş, araştırma sorgulamaya dayalı öğrenme anlayışı benimsenmiştir (MEB, 2013). 2017 programında ise bilimsel süreç, yaşam becerilerinin yanı sıra yenilikçilik ve girişimcilik ve düşünme becerileri ön plana çıkarılmıştır (MEB,2017).

Yaratıcılık, fen ile ilgili çalışmalardaki birçok bilimsel süreçte tamamlayıcı rol oynamaktadır. Çocuklar içinde bulundukları dünyayı anlamak için çok sayıda düşünme stili kullanırlar. Bunların içinde yaratıcı düşünme tarzı, bilimsel bilgi kadar, çocukların yaşadıkları evreni anlamaları için önemlidir (Koray,2004). Bu anlamda fenin diğer okul alanlarına göre yaratıcılığı daha çok geliştiren aktivitelere sahip olduğu ve bu nedenle yaratıcılığın fen programlarının içine entegre edilmesinin önemi ifade edilmektedir (Rule, 2005).

Grosul (2010) bilimsel yaratıcılığı; kullanışı ve adapte edilebilen bilimsel teoriler; araştırma yöntemleri veya ampirik bulgular üretmek için gerekli kişisel yetenek; bilim insanını sıra dışı ve kullanışı bir ürün üretmeye yatkın kılan kişisel nitelik olarak tanımlamıştır. Rawat (2010) ise; bilim ve teknoloji alanında eşsiz bir bilimsel süreç olarak tanımlamıştır. Mohammed (2006)'e göre bilimsel yaratıcılık ön bilgilere dayalı olarak bilimsel alanda problemleri hissetme, teori geliştirme, yeni özgün fikirler üretme ve ürünler koyma ile ilgili bilim etkinlikleridir. Genel olarak bilimsel yaratıcılık; geçmiş deneyimlere ve bilgilere dayalı olarak; problemlere ve bunların çözümlerine yönelik hassasiyet duyma, bilimsel bilginin doğasını anlama ve ona ilgi duyma ve yeni, sıra dışı ve kullanışlı bilimsel bilgiler, deneyler, teoriler ve ürünler yaratma yeteneği olarak tanımlanabilir.

Öğrencilerin bilimsel yaratıcılıklarının gelişmesinde bilgisayar destekli eğiti uygulamalarının önemli olduğu düşünülmektedir. Bilimsel kavram ve prensiplerin fen bilgisinde oldukça çok olması ve uygun öğretim tekniklerinin kullanıldığı ders yazııımları ile öğrenciye görsel ve duyusal olarak hitap edebilmesi (Demircioğlu ve Geban, 1996) BDÖ etkinliklerinin önemini arttırmaktadır. Bilgisayarların öğrenme sürecine katılması yeni öğretim yöntem ve tekniklerinin gelişmesine olanak sağlamıştr. Bu yöntemlerden biri de dijital öykülemedir.

Dijital öyküleme, değişen dijital dünyayı temele alarak geleneksel bir yöntemin günümüz teknolojik gelişmelerine paralel olarak tasarlanması ile oluşmuştur (Garcia ve Rossiter, 2010). Tatum (2009) dijital öykülemeyi sözlü, görsel ve hareketli sembollerle yazının 3-5 dakikalık videolar halinde birleştirilmesi olarak tanımlamıştır. Robin ve Pierson (2005) dijital öykülemeyi, öğrenci ve öğretmenlerin hayal güçlerini yakalayan ve onların deneyimlerini yücelten anlamlı öykülerin oluşturulması olarak ifade etmiştir.

Dijital öyküleme süreci öğrencilerin özgün düşünceler ortaya koymalarına olanak vermektedir. Bu süreçte öğrenciler kendi düşüncelerini oluşturmakta ve bunu yazarak ifade etmektedirler (Banaszewski, 2005). Yapılan araştırmalarda dijital öyküleme çalışmalarının öğrencilerin akademik başarılarını olumlu yönde etkilediği (Bromberg vd., 2013; Kahraman, 2013; Yang ve Wu, 2012; Wang ve Zhan, 2010), yaratıcılıklarını (Wu ve Yang, 2008) öğrencilerin yaratıcı yazma becerilerini(Duman ve Göçen, 2014), eleştirel düşünme becerilerini, problem çözme becerilerini (Hung, Hwang ve Huang, I., 2012; Robin,2006) geliştirdiği belirtilmektedir.

Ayvaz Tunç ve Karadağ (2013); öğrencilerin dijital öyküleme sürecini tasarlamasında öğrencilerin hayallerini, düşüncelerini ve yaratıcılıklarını ön plana çıkarmalarının öneminden bahsetmektedir. Ancak, yapılan çalışmalar dijital öykü oluşturma sürecini olumsuz etkileyebilecek durumların ortaya çıkabildiğini göstermektedir. Örneğin Sancar Tokmak, Sürmeli ve Özgelen (2014) üniversite öğrencileriyle yaptıkları çalışmada, öğrencilerin öykü oluşturma sürecinde çok zorlandıklarını, öğrencilerin yaratıcı düşünme ve görsel materyaller oluşturmada sıkınt yaşadıklarını göstermiştir (Sancar-Tokmak, Sürmeli, ve Özgelen,2014). Yüksekyalçın, Tanrıseven ve Sancar Tokmak (2016), yaptıkları araştırmalarında yaratıcı dramanın bu sorunların çözümünde etkin bir yöntem olabileceğini ifade etmişlerdir.

Adıgüzel (2014)'e göre yaratıcı drama, öğrenmeyi hayat içinde sunması, çocuğun bilgilerini özelleştirmesi, öğrenmeyi ve bilgiyi fonksiyonel kılması, öğrenmeyi aktif hale getirmesi ve öğrenmede öğrencilerin gelişimsel özelliklerini harekete geçirmesi açısından önemlidir. San (2002) yaratıcı dramayı, "doğaçlama, rol oynama vb. tiyatro ya da drama teknik- 
lerinden yararlanarak, bir grup çalışması içinde, bireylerin bir yaşantıyı, bir olayı bir fikri, kimi zaman bir soyut kavramı ya da davranışı, eski bilişsel örüntülerin yeniden düzenlenmesi yoluyla gözlem, deneyim, duygu ve yaşantıların gözden geçirildiği süreçlerde anlamlandırıması, canlandırıması" olarak tanımlamıştr. Bu süreçte dramanın oyunsu özelliği, yaratıcı edimlere ve yaratıcılık süreçlerine uygunluğu dikkati çekmektedir (Fleming,1994). McCaslin(2000) yaratıcı dramanın genel amaçları arasında farklı şekilde düşünme yeteneği geliştirme, hayal gücü ve estetik gelişimi sağlamadan bahsetmiştir. Ayrıca dramada hareket ve görsel elementler beyinde çoklu bağlantılar yaratır. Çocukların güvenli ve kendini ifade edebileceği bu ortamda hayal güçleri ve yaratııılıkları ortaya çıkmaktadır. (Kocayürek,2000;Uysal,1996). Fen derslerinde yaratıı drama kullanımının; öğrencilerin derse karşı tutumlarına (Sağılı ve Gürdal,2002) , ders başarılarına (Çam, Özkan ve Avinç,2009), eleştirel düşünme becerilerine (Yılmazlar, Yağmur ve Takunyacı, 2013), sözlü iletişimlerine, öğrencilerin deneyimlerini dünyaya anlatmalarına (Bentley ve Watts, 1989) olumlu katkı sağladığı belirlenmiştir.

Yapılan araştırmalarda hem dijital öykülemenin hem de yaratıcı dramanın öğrencilerin öğrenmeleri üzerinde önemli bir yer tutuğu gözlenmiştir. Ancak alan taramasında fen öğretiminde dijital öyküleme yönteminin yaratıcı drama ile birlikte kullanılmasını ele alan araştırmalara rastlanmamıştır. Öğrenme ortamında dijital öyküleme sürecinde yaratıcı drama kullanımının öğrencilerin bilimsel yaratıcılıkları üzerinde önemli katkılar sağlayacağı düşülmektedir. Bu yönü ile yapılan bu araştırmanın dramanın teknolojiyle bütünleştirilmesinin etkililiğini ortaya koyma anlamında alan yazına katkı sağlayacağı söylenebilir. Bu noktadan hareketle bu araştırmanın amacı, 7. Sınıf fen ve teknoloji dersinde dijital öyküleme sürecinde yaratıcı drama kullanımının öğrencilerin bilimsel yaratıcılık ve dijital öyküleri üzerindeki ortaya koymaktır. Bu amaç doğrultusunda şu sorulara cevap aranmıştır:

1. 7.sınıf öğrencilerinin fen ve teknoloji dersindeki bilimsel yaratıcılık son-test puanları deney ve kontrol grubu arasında anlamlı bir farklılık göstermekte midir?

2. Uzman görüşlerine göre deney ve kontrol grubundaki öğrencilerin oluşturdukları dijital öykülerin nitelikleri nasıldır?

3. Deney grubunda yer alan öğrencilerin dijital öyküleme sürecine ilişkin görüşleri nelerdir?

\section{Yöntem}

\section{Araştirma Deseni}

Araştırmada, nicel verileri nitel verilerle açıklamak amaçlandığından karma yöntem kullanılmıştır. Araştırma, karma yöntem desenlerinden açımlayıcı sıralı karma yöntem desenine uygun olarak düzenlenmiştir. Açıklayıcı karma yönteme dayalı araştırmalarda, nicel veriler toplanıp daha sonra nicel verileri açıklamak amacıyla nitel veriler toplanmaktadır (Creswell ve Plano Clark, 2011). Bu desene uygun olarak araştırmanın nicel boyutunda dijital öyküleme sürecinde yaratıcı drama kullanımının, öğrencilerin bilimsel yaratıcılıkları üzerindeki etkisini tespit etmek amacıyla "Öntest-Sontest Kontrol Gruplu Yarı Deneysel Araştırma Modeli" uygulanmıştr. Deney grubu ile yapılan derste dijital öyküleme sürecinde yaratıcı drama kullanılmış, kontrol grubu ile yapılan derste ise dijital öyküleme yoluyla öğrenme gerçekleştirilmiştir. Deney öncesi ve sonrası ölçme araçları nicel ölümler ön-test ve son test olarak her iki gruba da uygulanmıştr. Araştırmanın nitel boyutunda ise deney grubunda yer alan öğrencilere araştırma sonunda açık uçlu soru formu uygulanmıştr. Oluşturulan dijital öyküler "Dijital Öyküleme Rubriği” ile değerlendirilmiştir.

\section{Çalışma Grubu}

Araştırmanın çalışma grubunu, 2014-2015 öğretim yılında bir ortaokulun 7. sınıflarına devam eden toplam 50 öğrenci oluşturmaktadır. Araştırma kapsamında araştırmacı tarafindan başarı ortalamaları denk olan iki sınıf seçilmiştir. Sınıflar tesadüfi olarak deney ve kontrol grubu olarak atanmıştır. Deney ve kontrol gruplarında yer alan 25 öğrencinin 13'ü kız, 12'si erkek öğrenciden oluşmaktadır. Yapılan araştırmada seçilen grupların bilimsel yaratıcılık bakımından denk olup olmadığını tespit etmek için ön test puanları için İlişkisiz Örneklemler için T-Testi analizi yapılmış ve grupların birbirine yakın düzeyde olduğunu belirlenmiştir.

\section{Veri Toplama Araçları}

Bu araştırmada veri toplama aracı olarak "Bilimsel Yaratıcılık Ölçeği", "Dijital Öyküleme Rubriği" ve "Açık Uçlu Soru Formu" kullanılmıştır.

\section{Bilimsel Yaratıcılık Ölçeği}

Araştırmada öğrencilerin bilimsel yaratıcılıklarını ölçmek amacıyla "Bilimsel Yaratıcılık Testi" kullanılmıştır. Hu ve Adey (2002) tarafindan geliştirilen ölçme aracı, Deniş Çeliker ve Balım (2012) tarafindan 6, 7 ve 8. Sınıf öğrencileri için Türkçe'ye uyarlanmıştır. Bu test açık uçlu yedi sorudan oluşmaktadır. Bilimsel Yaratıcılık Yapı Modeli'nin ana boyutları olan süreç, karakter ve ürünün tüm alt boyutlarını ölçmektedir. Sorulara verilen cevaplar akıcılık, esneklik ve özgünlük açısından değerlendirilerek puanlanmaktadır. Sorular alışılmadık kullanımlar, problemi keşfetme, ürün geliştirme, bilimsel hayal gücü, problem çözümü, fen deneyi ve ürün tasarımı konularıyla ilgilidir. 
İlk dört soruda akıcılık, esneklik ve orijinallik puanları toplanmaktadır. Akıcılık puanı verilen farklı cevapların hesaplanmasıyla elde edilir. Esneklik puanı her bir alan ya da yaklaşım sayısının hesaplanması ile elde edilir. Orijinallik puanı hesaplanırken yapılarak verilen tüm doğru cevaplar içerisinde \%5' e giren öğrenciler 2 puan; \%5 ile \%10 arasına giren öğrenciler ise 1 puan almaktadır. Diğer doğru yanıtlara ise sıfır puan verilmektedir. Beşinci soruda, verilen cevaplar içerisinde \%5'e giren öğrencilere 3 puan, \%5 ile \%10 arasına giren öğrencilere 2 puan ve diğerlerine ise $1^{\prime}$ er puan verilmektedir. Altıncı soru esneklik ve orijinallik puanlarının toplamıdır. Esneklik puanı her bir doğru metot için en yüksek 9'dur. 3 puan araç, 3 puan ilkeler, 3 puan izlenen yoldan alınabilir. Orijinallik puanı daha önce olduğu gibi; verilen cevaplar içinde $\% 5^{\prime}$ in altında ise 4 puan $\% 5$ ile $\% 10$ arasında ise 2 puan yüzde $\% 10^{\prime}$ dan büyük ise 0 puan olarak hesaplanmıştır. Yedinci sorunun puanlanması elma toplama makinesinin işlevlerine göre ayarlanır. Her bir işlev 3 puan almaktadır. Orijinalliğe göre 1 ile 5 puan arasında puanlama yapılabilir. Akıcılık, esneklik ve orjinallik puanları belirtilen puanların toplamıyla elde edilmektedir. Ölçeğin Cronbach alfa iç tutarlılık katsayısı 0,86 ve test tekrar test korelâsyonu 0,91 olarak hesaplanmıştı(Deniş Çeliker ve Balım, 2012) Bu araştırma kapsamında bilimsel yaratıcılık ölçeğinin güvenirlik kat sayısı (CronbachAlpha) $\alpha=079$ olarak hesaplanmıştir.

\section{Dijital Öyküleme Rubriği}

Bu araştırmada öğrencilerin dijital öyküleme sürecinde oluşturdukları ürünlerin niteliğini belirlemek amacıyla "Dijital Öyküleme Rubriği" kullanılmıştır. Rubistar Web sitesinde paylaşılan rubrik; öğretmen çalışmalarına, Dr. Helen Barret ve Massachusetts Üniversitesi'nin çalışmalarına dayalı olarak oluşturulmuştur(Sample Rubric, 2014). Sancar-Tokmak ve İncikabı (2013), araştırmalarında öğretmen adaylarının dijital öykülerinin niteliğini tespit etmede veri toplama aracı olarak bu rubriği kullanmışlardır. Bu rubrik öykünün amacı, bakış açısı, önemli soru, içerik seçimi, sesin netliği, sözlü anlatımın temposu, anlamlı ses (Müzik) öğesi, resimlerin kalitesi, öykü uzunluğu, gramer ve dil kullanımı kategorilerinden oluşmuştur. Rubriğin değerlendirilmesi bu kategorilerin niteliğine ilişkin dört dereceli puanlamaya dayanmaktadır. Rubrikten elde edilen toplam puan dijital öykünün niteliğini göstermektedir (Sample Rubric, 2014). Dijital öyküleme rubriği analitik rubriktir. Bu rubrikler önce performans veya ürünün parçalarının ayrı ayrı puanlanmasını sonra da bu puanları toplayarak toplam puanın hesaplanmasını gerektirir. Rubrik öncelikle bilgisayar ve öğretim teknolojileri alanında uzman iki öğretim üyesi tarafindan bağımsız olarak İngilizce 'den Türkçe 'ye çevrilmiştir. iki çeviriden yola çıkılarak oluşturulan Türkçe form ile orijinal İngilizce form iki İngilizce uzmanı tarafindan incelenerek çevirinin uygunluğu tespit edilmiştir.

\section{Açık Uçlu Soru Formu}

Bu araştırmada deney grubunda yer alan öğrencilerin dijital öyküleme sürecinde yaratıcı drama kullanımına ilişkin görüşlerini belirlemek amacıyla araştırmacı tarafindan oluşturulan açık uçlu soru formu kullanılmıştr. Sorular araştırma sorularına paralel olacak şekilde dijital öyküleme sürecinde drama kullanımının öğrencilerin bilimsel yaratıcılıkları ve dijital öyküleri üzerindeki etkisini ortaya çıkaracak şekilde hazırlanmıştı. Bu amaçla soru formunda deney grubunda yer alan öğrencilere 2 adet açık uçlu soru yöneltilmiştir. Açı uçlu soru formu, öğrencilerin yazılı olarak yöneltilen soruları yazılı olarak cevaplamasına dayanmaktadır. Oluşturulan açık uçlu soru formu, 2 eğitim programları ve öğretim alanında uzman, 2 bilgisayar ve öğretim teknolojileri alanında olmak üzere toplam 4 öğretim üyesinin görüşüne sunulmuştur. Öğretim üyeleri soruları açıklık, anlaşıırlık, araştırma amacına uygunluk açısından değerlendirmişlerdir.

\section{İşlemler}

Araştırma, deney ve kontrol gruplarında araştırmacının kendisi tarafindan gerçekleştirilmiştir. Araştırmada 7. sınıf Işık Ünitesi kazanımları işlendikten sonra deney ve kontrol grubunda yer alan öğrencilerden 5'er kişilik 5 grup oluşturulmuştur. Her gruptan araştırma boyunca bir dijital öykü oluşturması istenmiştir. Araştırmanın uygulaması 7 hafta 28 ders saati olacak şekilde planlanmıştır.

Araştırmanın uygulama aşamasına geçmeden, hem deney grubu öğrencilerine hem de kontrol grubu öğrencilerine dijital öyküleme ve dijital öyküleme alt basamakları hakkında bilgi verilmiş; ayrıca deney grubu öğrencileri drama yöntemi hakkında bilgilendirilmiştir. Dijital öykü uygulamaları dijital öykülemelenin aşamalarına göre gerçekleştirilmiştir. Bu aşamalara göre gruplar öykünün başlangıç noktası, senaryonun oluşturulması, görsel ve işitsel materyallerin tasarlanması, görsel ve işitsel materyallerin hazırlanması, görsel ve işitsel materyallerin senaryo ile birleştirilerek dijital öykünün oluşturulması, dijital öykünün sunumu aşamalarını izlemişlerdir. Deney ve kontrol grubunda dersler yapılandırmacı yaklaşımın öngördüğü şekilde işlenmiştir. Deney grubunda dersler dijital öyküleme yöntemiyle birlikte yaratıcı drama yöntemi kullanılarak işlenmiştir. Dijital öykülemenin her bir aşamasında kazanımlarla ilgili olarak bir drama etkinliği yaptırılmış. Drama etkinlikleri ısınma, canlandırma ve değerlendirme aşamalarına göre planlanmıştır. Kontrol grubunda ise dersler yalnızca dijital öyküleme yöntemi kullanılarak işlenmiştir. Öğretmen tarafindan deney ve kontrol grubunda oluşturulan dijital öykülere ilişkin değerlendirme rubriği kullanılarak öğrencilere geri bildirim verilmiştir. Çalışma sonunda, deney ve kontrol grubuna, son test olarak bilimsel yaratıcılık ölçeği uygulanmıştr. Ayrıca deney grubunda yer alan öğrencilerin dijital öyküleme sürecine ilişkin görüşlerini belirlemek için açık uçlu soru formu uygulanmıştr. Her iki grubun dijital öykülerinin niteliği "Dijital Öyküleme Rubriği” ile belirlenmiștir. 


\section{Veri Analizi}

Araştırmada elde edilen verilerin normal dağılıma uygun olduğu gözlendiği için veri analizinde parametrik testler kullanılmıştır. 7. Sınıf öğrencilerinin bilimsel yaratıcılıklarının deney ve kontrol grubu arasında farklılık gösterip göstermediğini belirlemek için ilişkisiz gruplar için T-testi uygulanmıştır. Deney ve kontrol grubunda yer alan öğrencilerin oluşturuldukları dijital öykülerin niteliğinin değerlendirilmesinde uzman görüşlerine başvurulmuş, öyküler, dijital öyküleme rubriği yoluyla beş uzman tarafindan değerlendirilmiştir. Rubriğe göre oluşturulan dijital öyküler; öykünün amacı, bakış açısı, önemli soru, içerik seçimi, sesin niteliği, sözlü anlatım temposu, anlamlı ses(Müzik öğesi), resimlerin kalitesi, öykünün uzunluğu, gramer ve dil kullanımı açısından puanlanmıştır. Dijital öykülerin her biri D1, D2, D3, D4 ve D5 olarak kodlanmıştır. Her bir dijital öyküleme değerlendirmesine ilişkin uzman değerlendirmelerinin aritmetik ortalaması alınmıştır.

Deney grubunda yer alan öğrencilerin dijital öyküleme sürecine ilişkin görüşlerinin tespit edilmesinde açık uçlu sorulardan elde edilen veriler içerik analizi yoluyla analiz edilmiştir. Araştırma bulguları sunulurken öğrenci görüşlerinden aynen alıntılara yer verilmiştir. Veri analizi güvenirliğini sağlamak amacıyla görüşme sorularının her biri için Miles ve Huberman testi yapılmış araştırma verileri iki uzman tarafindan değerlendirilmiştir. Kodlayıcılar verileri birbirinden bağımsız olarak kodlamışlar. Miles ve Huberman (1994:64) benzeşen kodları "Görüş Birliği" ayrışan kodları ise "Görüş Ayrılığı" olarak adlandırmakta ve kodlayıcı güvenirliği için Uzlaşma Yüzdesi = Görüş Birliği / (Görüş Birliği + Görüş Ayrılığı) * 100 formülünü önermektedir. Kodlayıcı güvenirliği için Miles ve and Huberman katsayısı,79 olarak hesaplanmıştır.

\section{Bulgular}

Araştırmada 7.sınıf öğrencilerinin fen ve teknoloji dersindeki bilimsel yaratıcılıklarının deney ve kontrol grubu arasında anlamlı bir farklılık gösterip göstermediğine ilişkin olarak Ilişkisiz Örneklemler t-Testi yapılmış, sonuçlar Tablo 1'de sunulmuştur:

Tablo 1. Deney ve Kontrol Grubu Öğrencilerinin Bilimsel Yaratıcılık Son Test Puanları Ortalamalarına İlişkin ỉlişkisiz Örneklemler T-Testi Sonuçları

\begin{tabular}{lcccccc}
\hline Grup & $\mathbf{n}$ & $\mathbf{X}$ & $\mathbf{t}$ & $\mathbf{S d}$ & $\mathbf{t}$ & $\mathbf{p}$ \\
\hline Deney & 25 & 40,64 & 4,59 & \multirow{2}{*}{0} & \multirow{2}{*}{8,061} & 0.00 \\
Kontrol & 25 & 29,84 & 4,87 & & & \\
\hline
\end{tabular}

Tablo 1 incelendiğinde dijital öyküleme sürecinde yaratıcı drama çalışmalarına katılan deney grubundaki öğrencilerin bilimsel yaratıcılıklarının ortalamaları 40,64; dijital öyküleme sürecinde yaratıcı drama çalışmalarına katılmayan kontrol grubundaki öğrencilerin bilimsel yaratıcılıkları ortalamalarının 29,84 olduğu görülmektedir. Deney ve kontrol grubunun son test başarı aritmetik ortalamaları arasında anlamlı bir fark olup olmadığına ilişkin yapılan ilişkisiz Örneklemler için T-test sonuçlarına göre deney grubu ile kontrol grubu arasında deney grubunun lehine istatistiksel olarak anlamlı $(t(48)=0,64, p$ 0.05) bir fark bulunmaktadır Bu bulgu, dijital öyküleme sürecinde yaratıcı drama çalışmalarının öğrencilerin bilimsel yaratıcılıkları arttırmada etkili olduğunu göstermektedir.

Araştırmanın ikinci alt probleminde uzman görüşlerine göre deney ve kontrol grubunda yer alan öğrencilerin oluşturdukları dijital öykülerin nitelikleri araştıılmıştır. Uzmanların deney grubunda yer alan dijital öykülere ilişkin verdikleri puanlar tablo-2'de sunulmuştur

Tablo 2. Deney grubundaki öğrencilerin oluşturdukları dijital öykülerin dijital öyküleme rubriğine göre değerlendirilmesi

\begin{tabular}{lccccc}
\hline & D1 & D2 & D3 & D4 & D5 \\
\hline Öykünün amacı & 3.8 & 3.8 & 3.6 & 3.6 & 3 \\
Bakış açısı & 3.4 & 3.6 & 3.2 & 3.6 & 3.2 \\
Önemli soru & 3.4 & 3.6 & 2.8 & 3 & 3.6 \\
İçerik seçimi & 3.2 & 3.4 & 2.8 & 3 & 3 \\
Sesin niteliği & 2 & 2.8 & 2.4 & 3.6 & 3 \\
Sözlü anlatım & 2 & 2.8 & 2.8 & 3 & 2.8 \\
Müzik öğesi & 2.6 & 3.4 & 1.8 & 3.6 & 2.6 \\
Resim kalitesi & 2.6 & 3 & 2.6 & 2.8 & 2.2 \\
Öykünün uzunluğu & 3 & 3.2 & 3.2 & 3.2 & 3.6 \\
Gramer ve dil & 3 & 2.8 & 3 & 3.6 & 3.4 \\
Toplam & 29 & 32.4 & 28.2 & 33 & 30.4
\end{tabular}

Tablo 2 incelendiğinde Dijital Öyküleme Rubriğinden; D1, 29 puan, D2, 32.4 puan, D3, 28.2 puan, D4, 33puan, D5 ise 30.4 puan almıştır. D1 grubunun oluşturuldukları dijital öyküde en yüksek puanları; öykünün amacı, bakış açış ve önem-

| Kastamonu Eğitim Dergisi, 27(6), 2019| 
li sorudan aldığı en az puanları sesin niteliği ve sözlü anlatım temposu başlıklarından aldığı görülmektedir. D2'nin oluşturduğu dijital öyküde; öykünün bakış açısının iyi geliştirildiği ve öykünün anlamına katkı sağladığı belirtilebilir. Dijital öyküleme rubriğine göre D2 grubunun oluşturdukları dijital öykülerinde sesin niteliği, gramer ve dil kullanımı ile sözlü anlatım temposunun yetersiz olduğu görülmektedir. D3'ün oluşturduğu dijital öykü; öykü uzunluğu bakımından incelendiğinde öykünün kompozisyonun genel olarak iyi olmakla birlikte bazı bölümlerinin çıkartılması gerektiği anlaşılmaktadır. 3 grubunun oluşturdukları dijital öyküde sesin niteliği, anlamlı ses(müzik öğesi)ile resimlerin kalitesinin yetersiz olduğu görülmektedir. D3 grubunun hazırladığı dijital öyküde anlamlı ses öğesinde müzik öykünün anlamına çok katkı sağlamamasına rağmen dikkat dağıtmamaktadır. D4'ün oluşturduğu dijital öyküde gramer ve dil kullanımı doğrudur ve öykünün açıklığına katkı sağladığı şeklinde görüş ifade edilmektedir. D4 grubunun oluşturdukları dijital öykülerinde resimlerin kalitesinin yetersiz olduğu görülmektedir. D5'in oluşturduğu dijital öyküde öykünün içinde çözülmesi gereken bir soru bulunmakta ve bu soruya öykünün sonuna kadar bu soruya cevap aranmaktadır. D5 grubunun oluşturdukları dijital öyküde sözlü anlatım temposu, anlamlı ses(müzik öğesi) ve resimlerin kalitesinin yetersiz olduğu görülmektedir. D5 grubunun hazırladığı dijital öyküde özellikle sözlü anlatım temposunun eksikliği üzerinde durulmuştur. Uzmanların kontrol grubunda yer alan dijital öykülere ilişkin verdikleri puanlar tablo-3'te sunulmuştur.

Tablo 3. Kontrol grubundaki öğrencilerin oluşturdukları dijital öykülerin dijital öyküleme rubriğine göre değerlendirilmesi

\begin{tabular}{|l|c|c|c|c|c|}
\hline & K1 & K2 & K3 & K4 & K5 \\
\hline Öykünün amacı & 2.6 & 2.6 & 2.4 & 2.6 & 2.6 \\
\hline Bakış açısı & 2.4 & 2.6 & 2.4 & 2.6 & 2.6 \\
\hline Önemli soru & 2.2 & 2.6 & 3 & 2.4 & 2.6 \\
\hline İçerik seçimi & 2.6 & 2.6 & 2.4 & 2.4 & 2.6 \\
\hline Sesin niteliği & 2.6 & 2.4 & 1.6 & 1.6 & 2.2 \\
\hline Sözlü anlatım & 2 & 2 & 2 & 2 & 2.4 \\
\hline Müzik öğesi & 2.6 & 2 & 2 & 2.2 & 1.6 \\
\hline Resim kalitesi & 2.2 & 2.6 & 2.2 & 2 & 2.6 \\
\hline Öykünün uzunluğu & 3.2 & 2.6 & 2.6 & 2.6 & 2.8 \\
\hline Gramer ve dil & 2.6 & 2.6 & 2.4 & 2.4 & 2.4 \\
\hline Toplam & 28.2 & 24.6 & 23 & 22.8 & 24.4 \\
\hline
\end{tabular}

K1 grubunun oluşturuldukları dijital öykünün değerlendirilmesinde en yüksek puanların; öykünün uzunluğu, öykünün amacı, içerik seçimi, gramer ve dil kullanımı ile sesin niteliğinden alındığı görülmektedir. K1'in oluşturduğu dijital öyküde içerik seçiminin öykünün çoğu bölümleriyle uygun olan farklı bir atmosfer ve ton yaratılarak seçildiği gözlenmektedir. Ayrıca sesin niteliğinin oldukça iyi ve bazı bölümleri boyunca oldukça anlaşılır olduğu belirtilmektedir. K1 grubunun oluşturdukları dijital öykülerinde sözlü anlatım temposu, sesin niteliğinin ve resimlerin kalitesinin yetersiz olduğu görülmektedir. K2 grubunun dijital öykülerinde sözlü anlatım temposu, anlamlı ses(müzik öğesi) ve resimlerin kalitesinin yetersiz olduğu görülmektedir. K2 grubunun hazırladığı dijital öyküde özellikle sözlü anlatım temposunun eksikliği üzerinde durulmuştur. Bu öyküde tempo kullanılmaya çalışılmıştır ancak bu tempo öyküye fazla uygun değildir. Dinleyicinin öykü içine çekilmesi sağlanamamıştır. K3 grubunun oluşturuldukları dijital öykülerde kompozisyonunun genel olarak iyi olduğu belirtilmekte; ancak bazı bölümlerinin çıkarılması gerekmekte ve bazı bölümlerin detaylandırılması gerektiği ifade edilmektedir. K3'ün oluşturduğu dijital öyküde öykünün amacının uygun seçildiği belirtilmiştir. Ancak öyküde bir bakış açısının sunulmasına karşın öykünün genele anlamına katkı sağlamaya çalışılsa da öykünün her bölümüyle ilişkilendirilemediği ifade edilmiştir. K4'ün oluşturduğu dijital öyküde anlamlı ses(müzik öğesi) öğesinin uygun yapılması müziğin öyküye bir duygu sağladığı yani resimlerle müziğin uyum içinde olduğu ifade edilmektedir. Ayrıca sesin niteliğinin de oldukça iyi olduğu ve tüm öykü boyunca anlaşılır olduğu belirtilmiştir. K5 grubunun oluşturuldukları dijital öyküde sözlü anlatım temposunun kullanılmaya çalışıldığı görülmektedir. Ancak bu tempo öyküye fazla uygun değildir. Dinleyicinin öykü içine çekilmesi sağlanamamıştr.

Araştırmanın üçüncü alt probleminde deney grubunda yer alan öğrencilerin dijital öyküleme sürecinde yaratıcı drama kullanımına ilişkin görüşleri araştııımıştr. Bu amaçla öğrencilerin dijital öyküleme sürecinde yaratıcı drama kullanımının düşünme süreçleri üzerindeki etkileri hakkındaki görüşlerine ilişkin bulgular Tablo-4'te sunulmuştur.

Tablo 4. Dijital öyküleme sürecinde yaratıcı drama kullanımının öğrencilerin düşünme süreçleri üzerine etkileri

\begin{tabular}{llcc}
\hline Öğrenci görüşleri & & Frekans & Yüzde \\
\hline AKICILIK & Çok sayıda fikir üretme & 16 & 64 \\
\hline \multirow{2}{*}{ ESNEKLiK } & Fikirleri geliştirme & 8 & 32 \\
& Farklı fikri uygulama & 4 & 16 \\
& Ayrıntılı düşünme & 3 & 12 \\
\hline
\end{tabular}




\begin{tabular}{llcc}
\hline Öğrenci görüşleri & & Frekans & Yüzde \\
\hline & Hiç olmayan fikir & 8 & 32 \\
& İlginç fikir & 4 & 16 \\
ORJiNALLik & Farklı bakış açıları & 8 & 32 \\
& Farklı-değişik fikir & 20 & 80 \\
& Orijinal fikir & 8 & 32 \\
\hline
\end{tabular}

Tablo-4 incelendiğinde öğrencilerin dijital öyküleme sürecinde yaratıcı drama kullanımının düşünme süreçleri üzerine etkilerinin akıcılık, esneklik ve orjinallik olmak üzere üç tema altında toplandığı görülmektedir. Öğrencilerin akıcılık teması altındaki görüşleri "çok sayıda fikir üretme(16)"; esneklik teması altnndaki görüşleri "fikirleri geliştirme(8)", "farklı fikri uygulama(4)" ve "ayrıntlı düşünme(3) orjinallik teması altındaki görüşleri ise; "farklı-değiş̧ik fikir(20)", "orijinal fikir(8)", "hiç olmayan fikir(8)", "farklı bakış açıları(8)" ve "ilginç fikir(4)" kodları altında toplanmıştır.

Öğrencilerin akıcılık teması altındaki görüşlerinin büyük çoğunluğu çok sayıda fikir üretme kodu alttnda toplanmaktadır. Bu konuda Ö1, "Etkinlikleri yaparken o etkinliğe bir şey katmak için yeterince düşünme olanağına sahip oldum. Bu da benim çok sayıda fikir üretmemi sağladı" şeklinde görüşünü ifade etmiştir. Esneklik teması altında Ö8 dijital öyküleme sürecinde yaratıı drama kullanımının ürettiği fikirleri geliştirmede kendisine yardımcı olduğunu şu şekilde ifade etmiştir: "Dijital öyküleme sürecinde yaratıcı drama kullanımı düşünme süreçlerim üzerindeki en büyük etkisi fikirlerimi geliştirmem üzerinde oldu. Her konuyla ilgili bir fikir oluşturabiliyordum. Ancak basit kalabiliyordu. Drama uygulamalarında yaptı̆̆ımız etkinlikler sayesinde sürekli oluşturduğum fikirlerime yeni bir şeyler katmama yardımcı oldu. Böylece her seferinde fikirlerimi geliştirmeye çalıştım yaptığımız etkinlikleri hatrlayarak". Ö1 bu süreçte dramanın farklı fikirleri uygulamada kolaylık sağladığı yönünde görüş belirtmiştir: " Drama sırasında bir biriden çok farklı etkinlikler yapma şansına sahip olduk. Her etkinlik içinde çok farklı fikirler üretmemiz gerekiyordu. Mesela; bazı etkinliklerde bir oyun yazmamız gerekiyordu, bazısında da tasarım yapmamız gerekiyordu. Böylece oyun yazmamız gereken yerdeki fikri tasarıma, tasarım yapmamız gereken fikri de senaryo yazmada kullanabiliyorduk". Ö4 ise dijital öyküleme ve drama uygulamalarının ayrıntılı düşünmeye katkı sağladığını şu şekilde belirtmiştir: "Dijital öyküleme sürecinde drama kullanımı düşünme süreçlerim üzerinde çok olumlu etkileri olduğunu düşünüyorum. Şöyle ki; dersi işlerken aynı konu gruplara dağıtılıyordu. Bu sırada kimseninkine fikirlerimiz benzemesin diye çok ayrıntılı düşünmeye çalıştım. Dramayla konuyu tam olarak öğrendiğim için konunun ayrıntılarını da düşüncelerime ekleyebildim".

Orjinallik teması altında Ö6 bu sürecin farklı-değişik fikirler üretmesine olan katkısını şu şekilde ifade etmiştir: "Drama düşünmek için bize sonsuz kapılar açtr. Hiç olmayacak bir şeyi bile hayalde olsa drama ile oldurabildiğimiz için çok değişik fikirler oluşturma imkânı bulabiliyorduk. Belki de bazı etkinlikleri sınıfta yapsaydık fikirlerim daha basit oluyordu ama drama ile işleyince dersi değişik fikirler oluşturabildim".Ö10 ise drama sayesinde hiç olmayan fikirleri üretebildiğini şu şekilde belirtmiştir: "Dijital öykülemede drama kullanmak düşünme sürecimi olumlu etkilediğini düşünüyorum. Mesela hiç olmayan, daha önce karşılaşmadığım fikirleri üretebildiğimi fark ettim. Etkinlikleri yaparken bizden bazı tasarımları yapmamız istenmişti. Bunu yaparken de önce aklıma ne geliyorsa yazdım. Sonra bunları farklı bir yolla birleştirmeye çalıştığımda ortaya daha önce yapılmamış ve arkadaşlarımın bile aklıma gelmeyen şeyleri çıkarabildim". Ö22 bu süreçte farklı bakış açılarıyla konuya bakabildiğini belirtmiştir: "Drama konulara daha farkıı bakmamı sağladı. Sadece derslerde somut düşünmelerle olayları anlamaya çalışırken dramadan sonra hayal gücümüzü de kullanarak konuları anlamaya çalışacağımızı öğrendik. Hep aynı yollarla olaylara bakmamı farkı bakış açılarıyla da sorunları çözebileceğimizi öğrendik. Ö13 dijital öyküleme sürecinde yaratıcı drama kullanımın ilginç fikir üretmesine katkı sağladığını belirtmiştir: "Bu süreçte yaptığımız uygulamalar ilginç fikirler üretmemizi sağladı. Hayal gücümüz kullanarak ilginç fikirler üretebildik".

Öğrencilerin dijital öyküleme sürecinde yaratıcı drama kullanımının dijital öyküleri üzerindeki etkileri hakkındaki görüşlerine ilişkin bulgular Tablo-5'te sunulmuştur.

Tablo 5. Öğrencilerin dijital öyküleme sürecinde yaratıcı drama kullanımının dijital öyküleri üzerindeki etkileri hakkındaki görüşleri

\begin{tabular}{lll}
\hline Öğrencilerin görüşleri & Frekans & Yüzde(\%) \\
\hline Senaryo yazmayı kolaylaşttrma & 16 & 64 \\
Soyut kavramaları somut görsellere dönüştürme & 9 & 36 \\
Yaratıcı senaryolar oluşturma & 9 & 36 \\
Dijital öykülerdeki görsellere karar verme & 12 & 48 \\
Dijital öykülerin seslendirilmesini kolaylaşttrma & 5 & 20 \\
Dijital öyküleri oluştururken konuları düzenleme & 13 & 52 \\
\hline
\end{tabular}

| Kastamonu Eğitim Dergisi, 27(6), 2019| 
Araştırma bulgularına göre öğrenciler dijital öyküleme sürecinde yaratıcı drama kullanımının dijital öyküleri üzerindeki etkisini; "senaryo yazmayı kolaylaştırma(16)", "dijital öyküleri oluştururken konuları düzenleme(13)”"dijital öykülerdeki görsellere karar verme(12)", "soyut kavramaları somut görsellere dönüştürme(9)", "yaratıcı senaryolar oluşturma(9)" ve "dijital öykülerin seslendirilmesini kolaylaştırma(5)" şeklinde ifade etmişlerdir.

Ö25, "senaryo yazmayı kolaylaştırma" ile ilgili görüşünü şu şekilde ifade etmiştir: "Drama ile dijital öykü yapmak çok eğlenceli geçti. En başta işimizi çok kolaylaştırdı. Senaryo yazmak başlangıçta hep sıkıntılı geldi bize ne yazacağımızı bilemedik. Sınıfta öğrendiğimiz gibi kitap yazar gibi kitaba deftere bakarak senaryolarımız oluşturduk. Ama pek beğenmedik. Drama yapmaya başlayınca çok kolay bir senaryo yazdığımızı fark ettik. Drama yaparken bizden konularla ilgili küçük oyunlar yazmamız gerekiyordu. Buda dijital öykü senaryolarımızı şekillendirmemizi sağladı".

Ö8 dramanın dijital öyküleri oluştururken konuları düzenlemelerine yardımcı olduğu yönündeki görüşünü şu şekilde ifade etmiştir: "En başta konu başlıklarının neler olması gerektiğini bize drama gösterdi. Başlangıçta dijital öykülerimizde nelerin önemli olduğunu anlamakta güçlük çekmiştik. Ancak drama ile konularımızda neleri arkadaşlarımıza öğretmemiz gerektiğini anladık. Konular arasında ve öykü içerisinde nasıl bağ kurmamız gerektiğini drama ile öğrendik".

Ö20, dijital öyküleme sürecinde drama kullanmanın dijital öykülerdeki görsellere karar verme konusunda kendilerine yardımcı olduğunu şu şekilde ifade etmiştir: "Dramanın dijital öykülemeyi kolaylaştıran en büyük yanı görsel fotoğraf kareleri oluşturma aşaması. Dijital öykülerimizi yaratırken bilgisayar aşamasında fotoğraf toplamaya başlarken kısıtlanabiliyorduk. Çünkü internetten tam olarak istediğimiz fotoğrafları bulmakta zorlanıyorduk. Mesela bir makinenin çizimi internette yoktu. Ama drama da yaptiğımız bir çalışma bu makineyi öykümüze koyabileceğimizi öğrendik".

Öğrencilerin yarısından azının görüşlerinin soyut kavramaları somut görsellere dönüştürme kodunda yoğunlaştiğı belirlenmiştir. Ö2 bu konudaki görüşünü şekilde belirtmiştir: "Işığın kırılması konusunu sınıfta işlerken pek anlamamıştım. Ama drama ile işleyince soyut olan kavramları vücutlarımızı kullanarak canlandırdığımız için daha çok aklımızda yer eder hale geldi. Böylece gözümüzle göremediğimiz ışınların geçişleri soyut iken somut hale getireceğimizi öğrenmiş olduk".

Ö22 ise yaratıcı drama uygulamalarının dijital öyküleme sürecinde yaratıcı senaryolar oluşturmalarına katkı sağladığı yönünde görüşlerini şu şekilde ifade etmiştir: "Dijital öyküleme sürecinde en çok zorlandığımız şey senaryo yazmakt. Bizim konumuzda farklı fikirler üretebilecek bir konu değildi diye düşünmüştük. Ama drama yaptıktan sonra böyle olmadığını fark ettik. Drama bize her konuda farklı düşünme olanağı verdi. Örneğin hayal gücümüz kullanmamız için bize firsat verdi. Mesela bir ders konusunu çizgi filmle anlatmak hiç aklımıza gelmemişti. Ama drama yaptıktan sonra hayal gücümüz kullanarak değişik fikirler oluşturabildik. Değişik fikirle üretmek ise farklı bakış açılarıyla bakıp yeni bir senaryo yazmamızı sağladı".

Ö11 dramanın dijital öykülerin seslendirilmesini kolaylaştırma yönünde katkı sağladığını şu şekilde belirtmiştir: "Drama ile seslendirme yapmayı öğrenmiş olduk. Çünkü dijital öykülerimizde seslendirme yapmamız gerekiyordu. Drama da rol yaparken seslerimizi nasıl daha net ve güzel kullanmamız gerektiğini öğrenmiş olduk".

\section{Sonuçlar}

Araştırma, dijital öyküleme sürecinde drama kullanımının 7.sınıf öğrencilerinin fen ve teknoloji dersindeki bilimsel yaratıcılıkları üzerinde olumlu yönde etkiye sahip olduğunu ortaya koymuştur. Dijital öyküleme sürecinde öğrenci, temel olarak araştırma, karar verme, problem çözme ve yaratıcı düşünme gibi birçok becerisini kullanarak yaratıcılık göstergeleri içeren bir öykü oluşturmaktadır (Bedir Erişti, 2016; Duman ve Göçen, 2014). Jenkins ve Lonsdale'e (2007) göre dijital öyküleme etkinlikleri öğrencilerin yenilikçi yollarla problem çözmelerine ve yaratıcılıklarının gelişimine yardımcı olmaktadır. Alanyazın incelendiğinde dijital öyküleme yoluyla öğrenmenin öğrenenlerin yaratıcılıkları üzerindeki etkilerini ortaya koyan çalışmalar bulunduğu görülmektedir (Dupain ve Maguire, 2005; Jakes, 2006; Gyabak ve Godina, 2011; Yuksel, Robin ve Mcneil, 2011; Ayvaz Tunç ve Karadağ,2013; Turgut ve Kışla, 2015). Yapılan araştırmalarda dijital öykülemenin sınıf ortamında kullanılmasıyla öğrencilerin eleştirel düşünme, yaratıcı düşünme ve yaratıcılık vb. gibi becerilerinin geliştirdiği tespit edilmiştir (Robin, 2008; Sadik, 2008;Wu ve Yang , 2008).

Yapılan araştırmada dijital öyküleme yönteminin kullanıldığı deney grubu ve kontrol grubunun bilimsel yaratıcılıklarının uygulama sonrası artış göstermesine karşın bu artışın yaratıcı drama yönteminin uygulandığı deney grubunda daha fazla olması, yaratıcı dramanın bilimsel yaratıcılığı arttırmadaki etkililiğini göstermektedir. Yaratıcı drama uygulamaları bireye farklı yaşantıları gözlemleme imkânı sunmakta bu da bireyin kendi yaşamına farklı bakış açılarıyla bak- 
masını sağlamaktadır. Böylece bireyler karşılaşacağı sorunlara farklı çözümler üretmeye başlar (Selvi ve Öztürk,2000). Yaratıcı drama yönteminin yaratıcılık ve farklı düşünebilme becerisini de ortaya çıkardığı ifade edilmektedir (Morris, 2011; Selvi ve Öztürk,2000; Susar Kırmızı, 2009), Ulubey ve Toraman (2015) dramanın yaratıcılık, hayal gücü, farklı bakış açılarını kullanarak durumlara ve sorunlara çözüm üretmede, rolleri dışında imgesel deneyimler oluşturma, yeni formüller bulma gibi becerileri geliştirme firsatı sağladığı üzerinde durmuşlardır. Bu noktada araştırma sonucu, fen eğitiminde yaratıcı dramanın kullanımı ile ilgili ala yazın ile paralellik göstermektedir. Bu çalışma kapsamında öğrenci görüşlerinden elde edilen bulgular araştırmanın nicel bulgularını destekler niteliktedir. Öğrencilerin büyük çoğunluğu dijital öyküleme sürecinde yaratıcı drama kullanımının yaratıcı senaryolar oluşturmada oldukça yarar sağladığını ifade etmişlerdir. Ayrıca neden-sonuç ilişkisi kurarak farklı bakış açıları geliştirdiklerini ifade etmişlerdir. Yine öğrencilerin büyük çoğunluğu drama yönteminin kullanılarak işlenen derslerde çok sayıda fikir üretildiği, farklı-değişik fikirlerin ortaya çıktı̆ını ifade etmişlerdir

Araştırmadan elde edilen sonuçlar dijital öyküleme sürecinde drama kullanan deney grubunun öykülerinin niteliklerinin dijital öyküleme sürecinde drama kullanmayan kontrol grubuna göre daha yüksek olduğunu ortaya koymuştur. Araştırmada deney grubundaki öğrencilerin öykünün amacını kontrol grubundaki öğrencilere göre daha net ifade ettikleri belirlenmiştir. Çünkü drama kişinin problemler karşısında çok yönlü düşünerek kendisini geliştirip kendisini yaratıcı olarak ifade etmesini sağlamaktadır (Adıgüzel, 2006). Bu nedenle drama uygulamalarının öğrencilerin kendini ifade etmesi üzerinde olumu etkiye sahip olduğu söylenebilir. Bununla birlikte oluşturulan dijital öykülerde deney grubundaki öğrencilerin öykünün amacını çok daha anlaşılır ve net bir şekilde ortaya koyarken; kontrol grubu öğrencilerinin deney grubuna göre daha düşük puanlar aldığı belirlenmiştir. Susar Kırmızı(2009), yaptı̆̆ araştırmasında drama yönteminin öğrencilerin yazma becerilerinde ve yazmaya olan tutumlarında olumlu bir etkiye sahip olduğunu ortaya koymaktadır. Bu noktada dramanın öykünün yazılmasına önemli katkılar sağladığı düşünülebilir. Öğrencilerin görüşlerinden elde edilen bulgular bu görüşü destekler niteliktedir.

Araştırmada deney grubunda bulunan öğrencilerin kontrol grubunda bulunan öğrencilere göre içerik seçiminde daha başarılı oldukları görülmektedir. Yapılan araştırmalarda da dramanın en önemli öğelerinden birinin de içerik olduğu görülmektedir. Dramadaki içerik taklit edilemez. Drama bir amaç olarak görüldüğünde içerik özgünleşmektedir. Çünkü yaratıcı drama sürece odaklıdır, yaşantıların çoğu drama sırasında kendiliğinden yaşanır. Böylece kişi kendisini daha iyi ifade etmeyi, çok yönlü düşünmeyi ve yaratıcılığı öğrenir (Adıgüzel, 2006: 22-25; Çakır İlhan, Okvuran ve Adıgüzel, 2004: 4). Ayrıca araştırmada drama yönteminin kullanıldığı deney grubunda dil kullanımın daha olumlu yönde geliştiği belirlenmiştir. Çünkü drama, dil becerisi ve okuma-yazmanın çok yönlü öğretiminde güçlü ve etkili bir yöntemdir (Maden,2010). Alanyazın incelendiğinde dramanın dil gelişimini sağladığını gösteren birçok araştırma bulunmaktadır (Karateke,2006; Ünsal, 2005; Köklü, 2003). Drama dil öğretiminde metinleri, kavramları anlamlandırmada ve yeni örnekler oluşturmada kullanılabilen bir yöntemdir (Erhan, 2000; Sağırlı, 2001).Bu nedenle drama iletişim becerilerini (yazılı ve sözlü) , dil öğretiminde de kalıcı öğrenmeyi sağlayabilecek bir yoldur (Maden,2010). Bununla birlikte drama; dil yapıları için bir firsat sunmakta, kelime bilgisinin ve cümle yapılarının gelişimini sağlamaktadır (Baldwin ve Fleming, 2003).

Dijital öyküleme sürecinin en önemli basamaklarından biri de dijital öykülerin oluşturulması sürecidir. Bu aşamada öğrenciler, bazı bilgisayar ve internet yazılımlarını kullanarak dijital öykü öğelerini (seslendirme, dijital resimler, müzik vb.) birleştirirler (Kajder ve Swenson, 2004). Bu araştırma kapsamında deney grubunda yer alan öğrenciler yaratıcı drama yönteminin dijital öykülerini oluşturmada katkı sunduğunu belirtmişlerdir. Öğrencilerin yarısı drama etkinlikleri sırasında kullandıkları fotoğraf karelerini dijital öykülerinde de kullandıklarını, böylece dijital öykülerindeki görselleri daha kolay belirlediklerini ifade etmişlerdir. Uzmanlar da deney grubunun oluşturduğu dijital öykülerin resim kalitesine kontrol grubuna göre daha yüksek puanlar vermişlerdir. Öğrenci görüşlerinden elde edilen bulguların uzman görüşlerine göre dijital öykülerin niteliklerine ilişkin tespitleri ile uyumlu olduğu söylenebilir.

Araştırma sonuçları doğrultusunda öğrencilerde bilimsel yaratıcılığın gelişmesi için dijital öyküleme yönteminin yaygınlaştırılmasına yönelik olarak okullarda yeterli teknolojik alt yapının oluşturulması gerektiği düşünülmektedir. Araştırma kapsamında öğrenciler gruplar halinde dijital teknolojiyi kullanmışlardır. Yeterli donanım sağlandığında bireysel olarak her öğrencinin dijital öykü hazırlayıp sunması teşvik edilebilir. Bu araştırma kapsamın dijital öyküler oluşturulurken drama yöntemi kullanılmıştır. İleriki araştırmalarda dijital öyküler, öğrencileri aktif kılacak farklı öğretim yöntem ve teknikleri ile bütünleştirilerek oluşturulan öğretimin etkililiği incelenebilir

\section{Kaynakça}

Adıgüzel, Ö.(2006). Yaratıcı drama kavramı, bileşenleri ve aşamalar. Yaratıcı Drama Dergisi, 1(1), 17-27.

Adıgüzel, Ö.(2014). Eğitimde yaratıcı drama. Ankara: Pegem Akademi.

Ayvaz Tunç, Ö. ve Karadağ, E. (2013). Postmodern oluşturmacılığa dijital öyküleme. Eğitim ve Öğretim Araşttrmaları Dergisi, 2(4), $310-315$.

| Kastamonu Eğitim Dergisi, 27(6), 2019| 
Baldwin, P.\& Fleming K. (2003). Teaching literacy through drama creative approaches. London: Routledge Falmer.

Banaszewski, M. T. (2005). Digital storytelling: supporting digital literacy in grades 4-12. Unpublished master's thesis, Georgia Institute of Technology, Atlanta.

Bedir Erişti, S. (2016). Katılımcı tasarım temelli dijital öyküleme sürecinde ilköğretim öğrencilerinin yaratıclık göstergeleri. Turkish Online Journal of Qualitative Inquiry, 7(4), 462-492.

Bentley, D. \& Watts, M. (1989). Learning and teaching in school science. Philadelphia: Open University Press.

Çakır İlhan, A., Okvuran, A. ve Adıgüzel, Ö. (2004). Drama. İstanbul: Milli Eğitim Bakanlığı Yayınları.

Creswell, J. W., \& Plano Clark, V. L. (2011). Designing and conducting mixed methods research. Thousand Oaks, CA: Sage

Çam, F.; Özkan, E. ve Avinç, i. (2009) Fen ve teknoloji dersinde drama yönteminin akademik başarı ve derse karşı ilgi açısından karşılaştırmalı olarak incelenmesi: Köy ve merkez okulları örneği. Gazi Eğitim Fakültesi Dergisi, 29(2), 459-483

Demircioğlu, H. ve Geban, Ö. (1996). Fen bilgisi öğretiminde bilgisayar destekli öğretim ve geleneksel problem çözme etkinliklerinin ders başarısı bakımından karşılaştırılması. Hacettepe Üniversitesi Eğitim Fakültesi Dergisi, 12, 183-185.

Deniş-Çeliker, H. ve Balım, A. G. (2012). Bilimsel yaratıcılık ölçeğinin Türkçe’ye uyarlama süreci ve değerlendirme ölçütleri. Uşak Üniversitesi Sosyal Bilimler Dergisi, 5(2), 1-21.

Duman, B. ve Göçen, G. (2014, Nisan). Dijital öyküleme yönteminin öğretmen adaylarının yaratıcı yazma becerilerine etkisi 1. Avrasya Eğitim Araştırmaları Kongresi'nde sunulan bildiri, İstanbul.

Dupain, M. ve Maguire, L. (2005). Digital storybook projects 101: How to create and ımplement digital storytelling into your curriculum. http://www.uwex.edu/disted/conference/resource library/proceedings/05 2014.pdf adresinden alınmıştır.

Fleming, M.(1994). Starting drama teaching. London: David Furton Publishers.

Garcia, P. \& Rossiter, M. (2010). Digital Storytelling as Narrative Pedagogy. In D. Gibson \& B. Dodge (Eds.), Proceedings of SITE 2010--Society for Information Technology \& Teacher Education International Conference (pp. 1091-1097). San Diego, CA, USA: Association for the Advancement of Computing in Education (AACE). Retrieved September 25, 2018 from https://www.learntechlib.org/primary/p/33500/.

Grosul, M. V. (2010). In search oftthe creative scientific personality. Unpublished master's theses, San Jose State University. The Faculty of The Depertmant of Psychology

Gyabak, K. \& Godina, H. (2011). Digital storytelling in bhutan: a qualitative examination of new media tools used to bridge the digital divide in a rural community school. Computers and Education, 57(4), 2236-2243.

Hu, W. \& Adey, P. (2002). A scientific creativity test for secondary school students. International Journal Of Science Education, $24(4), 389-403$.

Hung, C. M., Hwang, G. J., \& Huang, I. (2012). A project-based digital storytelling approach for improving students' learning motivation, problem-solving competence and learning achievement. Educational Technology \& Society, 15(4), 368-379.

Jakes, D. (2006). Standards-proof your digital storytelling efforts. TechLearning. Retrieved from http://www.techlearning.com/story/

Jenkins, M.,\& Lonsdale, J. (2007). Evaluating the effectiveness of digital storytelling for student reflection. Paper presented at the ICT: Providing Choices For Learners And Learning. Proceedings ASCILITE Singapore.

Kahraman, Ö. (2013). Dijital hikâyecilik metoduyla hazırlanan öğretim materyallerinin öğrenme döngüsü giriş aşamasında kullanılmasının fizik dersi başarısı ve motivasyon düzeyine etkisi. Yayımlanmamış doktora tezi, Balıkesir Üniversitesi Eğitim Bilimleri Enstitüsü, Balıkesir.

Kajder, S., \& Swenson, J. (2004). Digital İmages in the language arts classroom. International Society for Technology in Education, 31(8), 18-46.

Karateke E. (2006). Yaratıcı dramanın ilköğretim ikinci kademede 6. sınıf öğrencilerinin yazılı anlatım becerilerine olan etkisi. Yayınlanmamış yüksek lisans tezi, Mustafa Kemal Üniversitesi Sosyal Bilimler Enstitüsü, Hatay.

Kocayürek, A.(2000). Illköğretim öğrencilerinin sosyal becerilerini geliştirmede dramanın etkisi. Yayımlanmış yüksek lisans tezi, Ankara Üniversitesi, Sosyal Bilimler Enstitüsü, Ankara.

Koray, Ö. (2004). Fen eğitiminde yaratıcı düşünmeye dayalı öğrenmenin öğretmen adaylarının yaratıcı düşünme düzeylerine etkisi. Kuram ve Uygulamada Eğitim Yönetimi Dergisi, 40, 580-599.

Köklü, S. (2003). Türkçe öğretiminde 7. ve 8. sınıf öğrencilerine dinlediğini anlama davranışının kazandırılmasına dramatizasyonun etkisi. Yayınlanmamış Yüksek Lisans Tezi, Marmara Üniversitesi Eğitim Bilimleri Enstitüsü, İstanbul

Maden,S. (2010). Türkçe öğretmenlerinin drama yöntemini kullanmaya yönelik özyeterlilikleri. Mustafa Kemal Üniversitesi Sosyal Bilimler Enstitüsü Dergisi, 7(14), 259-274.

Matthews, N. \& Sunderland, N. (2013) Digital life-story narratives as data for policy makers and practitioners: thinking through methodologies for large-scale multimedia qualitative datasets. Journal of Broadcasting \& Electronic Media, 57(1), 97 - 114

Mc Caslin, V. (2000). Creative drama in the classroom and beyond. London: Longman

MEB. (2000). İlköğretim okulu fen bilgisi dersi (4, 5, 6, 7, 8. sınıf) öğretim programı. MEB Tebliğler Dergisi, 63,2518

MEB. (2013). ilköğretim kurumları (ilkokullar ve ortaokullar) fen bilimleri dersi (3, 4, 5, 5, 6, 7 ve 8. sınıflar) öğretim programı. Ankara: Milli Eğitim Basımevi

MEB. (2017). ilköğretim kurumları (ilkokullar ve ortaokullar) fen bilimleri dersi (3, 4, 5, 5, 6, 7 ve 8. sınıflar) öğretim programı. Ankara: Milli Eğitim Basımevi

Miles, M, B., \& Huberman, A. M. (1994). Qualitative data analysis: an expanded sourcebook. (2nd Ed). Thousand Oaks, CA: Sage. 
Mohammed, A.(2006). Investigating the scientific creativity of fifth-grade students (Yayımlanmıs doktora tezi).The University of Arizona, Arizona.

Morris, R. J.(2011). Responses of listener-viewers in digital storytelling: Collaborations in the intermediate classroom and the middle school library. Unpublished phD thesis,. University of Pittsburgh, Pittsburgh.

Rawat, T.C. (2010). a studty to examine fluency companent of scientific creative talent of elementary stage student of himachol paradesh with respect to area, type of school and gender. International Transactions in Humanities and Social Sciences, 2(2), $152-161$.

Robin, B. R. (2006). The educational uses of digital storytelling. C. Crawford vd. (Ed.), Proceedings of Society for Information Technology \& Teacher Education International Conference, 709-716. Chesapeake, VA: AACE.

Robin, B. \& Pierson, M. (2005). A multilevel approach to using digital storytelling in the classroom. C. Crawford vd. (Ed.), Proceedings of Society for Information Technology \& Teacher Education International Conference, 708-716, Chesapeake, VA: AACE.

Robin, B. R. (2008) Digital storytelling: a powerful technology tool for the 21st century classroom. Theory Into Practice, 47:3, $220-228$.

Rule,L.(2005).Digital storytelling workshop. http:// homepage.mac.com/eportfolios/workshop/AgendaDigitalStory.html adresinden alınmıştr.

Sadik, A. (2008). Digital storytelling: A meaningful technology-integrated approach for engaged student learning. Educational Technology Research and Development, 56, 487-506.

Sağırlı, H. E. ve Gürdal, A. (2002).Fen bilgisi dersinde drama tekniğinin öğrenci tutumuna etkisi. V. Ulusal Fen Bilimleri ve Matematik Eğitimi Kongresinde sunulan bildiri, Ankara.

Sample Rubric. (2014). Retrieved from, http://digitalstorytelling./coe.uh.edu/pdfs/samplerubric.pdf

San, i. (2002). "Yaratıcı Drama -Eğitsel Boyutları" Yaratıcı Drama 1985-1995 Yazılar. (Edt. H. Ömer Adıgüzel,). Ankara: Naturel Yayınları.

Sancar-Tokmak \& Lutfi Incikabi (2013) The effect of expertise-based training on the quality of digital stories created to teach mathematics to young children. Educational Media International, 50(4), 325-340.

Sancar-Tokmak, H., Surmeli, H., \& Ozgelen, S. (2014). Preservice science teachers' perceptions of their tpack development after creating digital stories. International Journal Of Environmental And Science Education, 9(3), 247-264.

Saxena, S.P., ve Khandelwal, B.P. (1994) Creativity and science education. http://www.education.nic.in/cd50years/q/6J/BJ/6JBJ0401. htmm adresinden 20.01.2015 adresinden alınmıştır.

Selvi, K ve Öztürk, A..(2000). Yaratıcı drama yöntemi ile fen öğretimi, Eğitim Bilim, 116(25), 42-46

Susar Kırmızı, F. (2009). Türkçe dersinde yaratıcı drama yöntemine dayalı yaratıcı yazma çalışmalarının yazmaya yönelik tutuma etkisi. Yaratıcı Drama Dergisi,4(7), 51-67.

Tatum, M. E. (2009). Digital storytelling as a cultural- historical activity: effects on information text comprehension. Open access dissertations, University of Miami: USA.

Turgut,F. ve Kışla, T. (2015). Bilgisayar destekli hikâye anlatımı yöntemi: Alanyazın araştırması. Turkish Online Journal Of Qualitative Inquiry, 6(2), 97-121.

Ulubey, Ö, Toraman, Ç. (2015). Yaratıcı drama yönteminin akademik başarıya etkisi: bir meta-analiz çalışması. Mustafa Kemal Üniversitesi Sosyal Bilimler Enstitüsü Dergisi, 12 (32), 195-220.

Uysal, F.N.(1996). Anaokuluna giden 5-6 yaş grubu çocuklarda yaratıcı drama çalışmalarının sosyal gelişim alanına olan etkisinin incelenmesi. Yayınlanmış yüksek lisans tezi, Ankara Üniversitesi, Sosyal Bilimler Enstitüsü, Ankara.

Ünsal, B. (2005). İlköğretim ikinci kademe (6, 7, 8. sınıflar) Türkçe dersinde drama yönteminin çocukların dil ve anlatım becerilerine katkısı. Yayımlanmamış yüksek lisans tezi, Gazi Üniversitesi, Eğitim Bilimleri Enstitüsü, Ankara.

Wang, S.,\& Zhan, H. (2010). Enhancing teaching and learning with digital storytelling. International Journal Of Information And Communication Technology Education, 6(2), 76-87.

Wu, W.C.\& Yang, Y.T. (2008). The impact of digital storytelling and of thinking styles on elementary school students' creative thinking, learning motivation, and academic achievement. K. McFerrin v.d. (Ed.), Proceedings of Society for Information Technology \& Teacher Education International Conference, 975-981, Chesapeake, VA: AACE.

Yang, Y. T. C., \& Wu, W. C. I. (2012). Digital storytelling for enhancing student academic achievement, critical thinking, and learning motivation: A year-long experimental study. Computers And Education, 59(2), 339-352

Yılmazlar, M., Yağmur Kolcu, E. Ve Takunyacı, M. (2013). The effect of 7th grade science and technology class on critical thınkıng skill and success when taught with the support of creative drama. International Refereed Academıc Social Sciences Journal, 12(4), 37-48.

Yüksekyalcin, G.; Tanriseven, I. \& Sancar-Tokmak, H. (2016). Mathematics and science teachers' perceptions about using drama during the digital story creation process. Educational Media International, 53(3), 216-227.

Yüksel, P., Robin, B. \& McNeil, S. (2011). Educational uses of digital storytelling around the world, Proceedings of Society for Information Technology and Teacher Education International Conference, Chesapeake, VA: AACE, 1: 1264-1271. 